\title{
Human Capital Investments Among Veterinarians
}

\author{
David M. Smith \\ Pepperdine University
}

\author{
Samuel L. Seaman \\ Pepperdine University
}

\author{
Yury Adamov \\ Pepperdine University
}

\begin{abstract}
Professional labor markets can be affected by alternating periods of excess or scarcity in labor. The phenomenon is most prevalent in labor markets where a substantial lag occurs between occupational choice and labor market entry. In this paper, a unique longitudinal dataset from veterinary labor markets is used to identify factors significantly associated with volatility in labor supply. Our econometric analysis establishes a statistically significant relationship between boom-bust cycles in labor and certain pertinent variables: entry-level earnings, a demand proxy, and supply-side features. Results support the notion that decision-makers gauge the expected levels of these variables when making career choices.
\end{abstract}

Keywords: human capital, earnings expectations, rational expectations, occupational choice

\section{INTRODUCTION}

Cobweb models were first proposed in agriculture markets, where there is a lag between production decisions and supply. Ezekiel (1938) illustrated the adaptive expectations that drive the fluctuations in these markets. More recently, economists, most notably Freeman (1975a, 1975b, 1976a, 1976b, 1989), have applied these models to professional labor markets where recurrent, systematic fluctuations in employment and earnings occur. Freeman has detailed these cyclical patterns in the labor markets for engineers, physicists, and lawyers and espouses the cobweb phenomenon to explain shortages and surpluses in labor supply. A fundamental attribute of the cobweb model is myopic expectations. In the case of the farmer, decisions on crop production occur well before the harvest. In the case of professional labor markets, an individual chooses whether to train for a highly skilled profession based on labor market conditions at the onset of their training program, which in some occupations, such as those mentioned above, can be lengthy.

The market for lawyers provides a good illustration of the fundamentals of a cobweb model. Suppose that in period t, there is an exogenous increase in the demand for legal services, which results in higher wages for lawyers. The cobweb model asserts that college graduates will behave in a myopic fashion and assume that salaries for lawyers will remain high indefinitely. As a result, a greater number of college graduates will choose to enroll in law school, resulting in a surplus of lawyers at graduation. This excess will reduce earnings, inducing a smaller cohort of college graduates wishing to enroll in law school. Upon 
graduation, this smaller cohort will enjoy higher earnings, tempting many to enroll in law school. This cycle will generally continue, ad infinitum. Freeman contends that myopic behavior on the part of human capital investors may be responsible for this disequilibrium.

Leffler and Lindsay (1979) establish evidence of myopic expectations in the labor market for physicians; Borghans et al. (1996) conclude that the cobweb model characterizes well data derived from their study of vocational choices amongst Dutch technical students. Billiot et al. (2004) corroborate a cobweb phenomenon for the accounting profession, showing that salary performance and certain supplyside factors predict changing enrollments. Haas, J. (2005), in a study of German labor markets, describes a recursive loop phenomenon between enrollments in science education and concurrent trends in German labor markets. More recently, Altonji et al. (2012) conducted a comprehensive meta-analysis over multiple fields of study, showing that labor market outcomes do indeed depend upon the specificity of human capital and, importantly, on uncertainty about occupational preferences (student-level variables). Long et al. (2015) found that choice of college majors are most strongly related to wages observed three years earlier, when students were college freshmen, again supporting the notion of myopic expectations. Finally, Weinstein (2017) reveals that human capital investments based upon national rather than local demand may increase regional labor market volatility.

Others, however, believe that decision-makers will not expect the future to be exactly as the present. Instead, they will use a more sophisticated framework - often termed the rational expectations model. These rational decision-makers construct informal, predictive models based on various factors affecting the longterm value of an occupational choice. Zarkin (1985), for example, provides evidence that the decision to enter a teaching profession is frequently motivated by rational analysis of future labor market conditions. In analyzing students' choices of college majors, Berger (1988) demonstrates that human capital investors are surprisingly adept at forecasting future earnings streams. Studies by Siow (1984) and Hoffman \& Low (1983) offer additional support for the rational expectations model.

Inferences from these studies, however, may be suspect. Connelly (1989) is critical of many of the findings in Siow's work. Generalizations based on Zarkin's work may be problematic since the author relies heavily on theoretical argument rather than convincing empirical evidence. (Zarkin acknowledges that while his model offers a good characterization of data for elementary school teachers, the results are less conclusive among secondary school teachers).

More recent work based on empirical investigation offers evidence that labor market decision-makers adopt more rational processes than the simple algorithm hypothesized by the cobweb or myopic expectations model. For example, Ryoo \& Rosen (2004) report that engineering majors use forward-looking fundamentals to predict the likely demand for engineers better. Lee (2010) analyzed a comprehensive data set (High School and Beyond) spanning 1960 through the 1990s to evaluate the impacts of salary changes and unemployment figures on occupational choice. Lee's findings were somewhat ambiguous and only modestly significant in most cases; still, the author was able to conclude that occupational choice appears not to be solely impacted by salary expectations or by local unemployment rates. Clark (2015) investigated occupational choice amongst those who declared engineering a major and discovered that a decision to switch majors during a course of study was not altogether myopic; instead, students behave more flexibly, adopting their assumptions about the persistence of relevant factors, such as salary and unemployment. The author suggests that when students leverage rational expectations, they are less likely to change majors where labor markets experience cyclical variability.

The cobweb and rational expectations models offer very different perspectives on labor market dynamics. As a further complexity, those espousing the two competing models often insist on the most extreme variant of their preferred archetype. Those who embrace myopic expectations believe that human capital investors will focus exclusively on starting wages, ignoring other labor market dynamics that may impact lifetime earnings.

Advocates of the rational expectations model, on the other hand, insist that human capital investors can perfectly anticipate future states of the labor market. Criticisms of these extreme views on earnings expectations are understandable, and in reality, the truth is likely somewhere in the middle (a hybrid rational-choice model). 
The two explanations for how earnings expectations are formed can have very different public policy implications. With the cobweb (myopic expectations) model, forecast errors by human capital investors are probable, resulting in long periods of disequilibrium. There is a unique opportunity for policymakers to help prospective students make better-informed decisions regarding their career choices. Under the rational expectations model, human capital investors may realize the error in their predictions, not unlike errors in professional forecasts, since both have the same information. They are assumed to be equally (or more) adept in their ability to predict the future relative to policymakers.

This paper tests the expectancies and consequences of both cobweb and rational expectations models with data from the labor market for veterinarians and related economic variables. As these models are often applied to labor markets having a close link between education and occupation, the veterinarian labor market is a valid testing ground. Moreover, the cobweb model is best tested in entry-level markets. This is precisely the level at which our data was collected, making our paper unique among other studies on this issue.

\section{SUMMARY STATISTICS}

Education for a veterinarian requires a minimum of six years of training, including at least two years of study in a pre-veterinary program and four years in a college of veterinary medicine. ${ }^{1}$ The vast majority of successful applicants to veterinary programs attain a bachelor's degree before attending veterinary school. After obtaining a Doctor of Veterinary Medicine (DVM) degree and passing a national board examination, most states will allow individuals to apply for licensure without further training (U.S. Department of Labor, 2014). In 2001, according to data from the American Veterinary Medical Association (AVMA), $85 \%$ of veterinarians were employed in the private clinical sector and $15 \%$ in the public and corporate sectors. Of those in the private clinical sector, $73 \%$ were employed in small animal practices, $15 \%$ in large animal practices, and the remainder in "mixed" (small and large) firms.

Table 1 reports census data on veterinary employment since 1900 . The data confirm varying periods of growth and decline in the number of total veterinarians and veterinarians as a percentage of the labor force. After growing from 1900 to 1920, the number of veterinarians declined up until 1950. In part, this may be explained by farmers' dependence on fewer animals, with greater reliance on tractors for production. From 1950 to 2000, the number of veterinarians as a percentage of the labor force had steadily increased, with an exceptionally high growth period from 1970 to 1980, when veterinary employment grew by $76 \%$. A reported decline occurred from 2000 to 2010 , but this may be related to changes in how the U.S. government surveys and estimates veterinary employment.

TABLE 1

VETERINARY EMPLOYMENT 1900-2010

\begin{tabular}{rrrrr}
\hline Census Year & Veterinarians & $\begin{array}{c}\text { \%Change in } \\
\text { Employment }\end{array}$ & $\begin{array}{c}\text { (Veterinarians/ } \\
\text { Labor Force) } \\
\mathbf{1 0 , 0 0 0}\end{array}$ & $\begin{array}{c}\text { \% Change in } \\
\text { (Veterinarians/ } \\
\text { Labor Force) }\end{array}$ \\
\hline 1900 & 5,149 & - & 1.77 & - \\
1910 & 11,652 & 126.3 & 3.12 & 76.2 \\
1920 & 13,494 & 15.8 & 3.20 & 2.3 \\
1930 & 11,863 & -12.1 & 2.44 & -23.8 \\
1940 & 10,717 & -9.7 & 2.07 & -15.0 \\
1950 & 11,460 & 6.9 & 1.96 & -5.5 \\
1960 & 15,365 & 34.1 & 2.26 & 15.4 \\
1970 & 19,176 & 24.8 & 2.39 & 6.0 \\
1980 & 33,746 & 76.0 & 3.48 & 45.4 \\
\hline
\end{tabular}




\begin{tabular}{rrrrr}
\hline Census Year & Veterinarians & $\begin{array}{c}\text { \%Change in } \\
\text { Employment }\end{array}$ & $\begin{array}{c}\text { (Veterinarians/ } \\
\text { Labor Force) } \\
\mathbf{1 0 , 0 0 0}\end{array}$ & $\begin{array}{c}\text { \% Change in } \\
\text { (Veterinarians/ } \\
\text { Labor Force) }\end{array}$ \\
\hline 1990 & 48,258 & 43.0 & 4.17 & 19.9 \\
2000 & 59,000 & 22.3 & 4.25 & 1.9 \\
2010 & 54,480 & -7.7 & 3.54 & -16.7 \\
\hline
\end{tabular}

Sources:

- U.S. Department of Commerce, Bureau of the Census. Subject Reports, Occupational Characteristics, Washington DC.

- U.S. Department of Labor. Occupational Outlook Handbook. Washington DC.

To examine the supply of new veterinarians available in the labor market, Figure 1 reports the number of first-year veterinary students as a proportion of annual bachelor degree recipients from 1950 to 2010 . The figure shows substantial variability over the period: the ratio of bachelor degree recipients enrolling in veterinary school increased from $.20 \%$ in 1950 to $.32 \%$ in 1955 , falling back to $.25 \%$ in 1960 ; after rising modestly in the early ' $60 \mathrm{~s}$, the rate fell to a low of .17\% in 1970 ; after increasing to $.24 \%$ in 1980 , this supply variable has experienced a secular decline with some periods of cyclical variation. While these peakto-trough fluctuations do not follow a rigid pattern, they appear to be consistent with the cyclical variations posited by the cobweb model.

FIGURE 1

SUPPLY OF NEW VETERINARIANS, 1950-2010

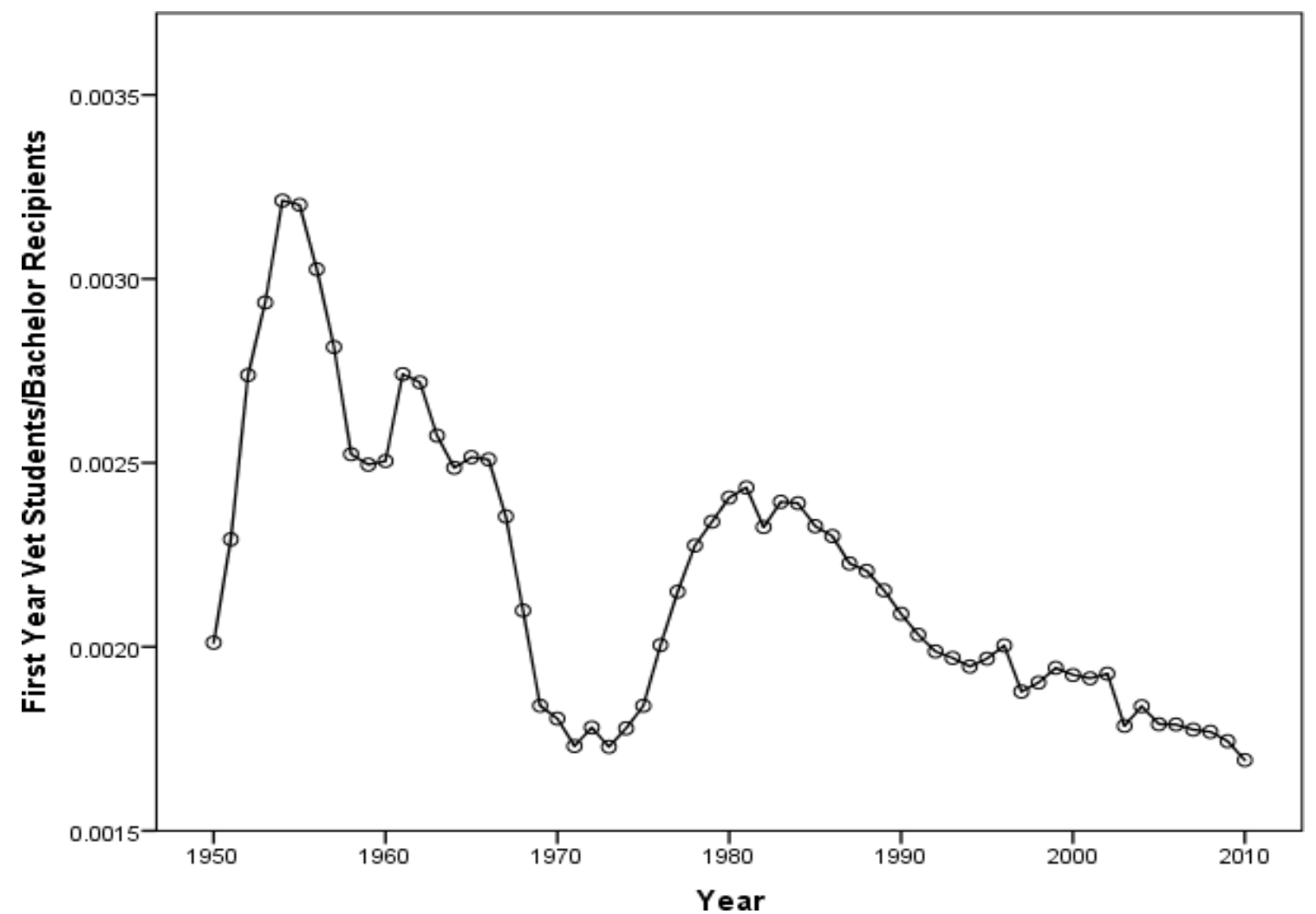

Represents the ratio of first year veterinary students over bachelor degree recipients for the period 1950 - 2010. Sources:

- U.S. Department of Education, Earned Degrees Conferred. Washington DC.

- American Veterinary Medical Association. Student Enrollment Statistics. Journal of the American Veterinary Medical Association. Schaumburg, IL. 
Table 2 reports census data on the earnings of veterinarians, along with physicians and the total labor force for the period 1950 to 2010. From 1950 to 1960, mean veterinarian earnings increased, in real terms, by $77.1 \%$, far outpacing the increase in compensation for physicians and the total labor force. After increasing from 1960 to 1970, veterinarian earnings fell from 1970 to 1980, both in absolute terms and relative to physicians and the total labor force. Real earnings recovered somewhat from 1980 to 2000, but lagged behind earnings gains made by physicians and the general labor force. Some modest growth in real earnings occurred for all three groups between 2000 and $2010 .^{2}$

TABLE 2

EARNINGS OF VETERINARIANS, PHYSICIANS, AND THE TOTAL LABOR FORCE, 1950-2010

\begin{tabular}{crrrrrr}
\hline $\begin{array}{c}\text { Census } \\
\text { Year }\end{array}$ & $\begin{array}{c}\text { Veterinarian } \\
\text { Earnings }\end{array}$ & $\begin{array}{c}\text { \% } \\
\text { Change }\end{array}$ & $\begin{array}{c}\text { Physician } \\
\text { Earnings }\end{array}$ & $\begin{array}{c}\text { \% } \\
\text { Change }\end{array}$ & $\begin{array}{c}\text { Total Labor } \\
\text { Force Earnings }\end{array}$ & $\begin{array}{c}\text { \& } \\
\text { Change }\end{array}$ \\
\hline 1950 & 30,153 & - & 59,320 & - & 16,863 & - \\
1960 & 53,394 & 77.1 & 83,907 & 41.4 & 23,102 & 37.0 \\
1970 & 70,504 & 32.0 & 104,904 & 25.0 & 27,095 & 17.3 \\
1980 & 61,102 & -13.3 & 110,891 & 5.7 & 27,803 & 2.6 \\
1990 & 67,233 & 10.0 & 148,203 & 33.6 & 34,597 & 13.3 \\
2000 & 68,620 & 2.1 & 137,400 & -7.3 & 39,243 & 35.6 \\
2010 & 73,103 & 6.5 & 145,177 & 5.7 & 42,049 & 7.2 \\
\hline
\end{tabular}

${ }^{1}$ Earnings as defined by the Census Bureau for the year preceding the census. For 2010, total labor force earnings are from the U.S. Bureau of Economic Analysis, Survey of Current Business. Figures for 1950, 1960, and 1970 are medians, and for 1980, 1990, 2000, 2010, means. All earnings figures are deflated by the Consumer Price Index and expressed in the year 2000 dollars.

Sources:

- U.S. Bureau of Economic Analysis, Survey of Current Business, Washington DC.

- U.S. Department of Commerce, Bureau of the Census. Subject Reports, Occupational Characteristics, Washington DC.

- U.S. Department of Commerce, Bureau of the Census. Earnings by Occupation and Education. Washington DC.

- U.S. Department of Labor. Occupational Employment Statistics. Washington DC.

Tables 1 and 2 reveal variability in veterinary employment and earnings consistent with the cyclical fluctuations found in other professional labor markets. However, the analysis of earnings expectations and human capital investments is most relevant to the market for new entrants, and thus, this market warrants closer examination.

Since 1978, the AVMA has conducted an annual survey on veterinary graduates' employment and starting salaries. Fig. 2 reports the mean starting salary for veterinary graduates entering private practice for the period 1978 to 2012. For comparison, first-year medical resident stipends, from data collected by the American Association of Medical Colleges (AAMC), are reported over the same time period. Since physicians and veterinarians have similar training, it seems appropriate to consider resident salaries as the opportunity wage for veterinarians.

Fig. 2 shows real starting salaries for veterinarians falling from 1978 to 1986, at which point they started a slow recovery that continued through 2010 , with a slight decline in earnings reported for the last two years. Medical resident stipends show more variability and a cyclical pattern, with long-run growth over the period of consideration. Visually, it is not clear if and how these two salary profiles are correlated. 


\section{FIGURE 2}

\section{VETERINARIAN STARTING SALARIES VS. YOUNG PHYSICIAN EARNINGS 1978-2012}

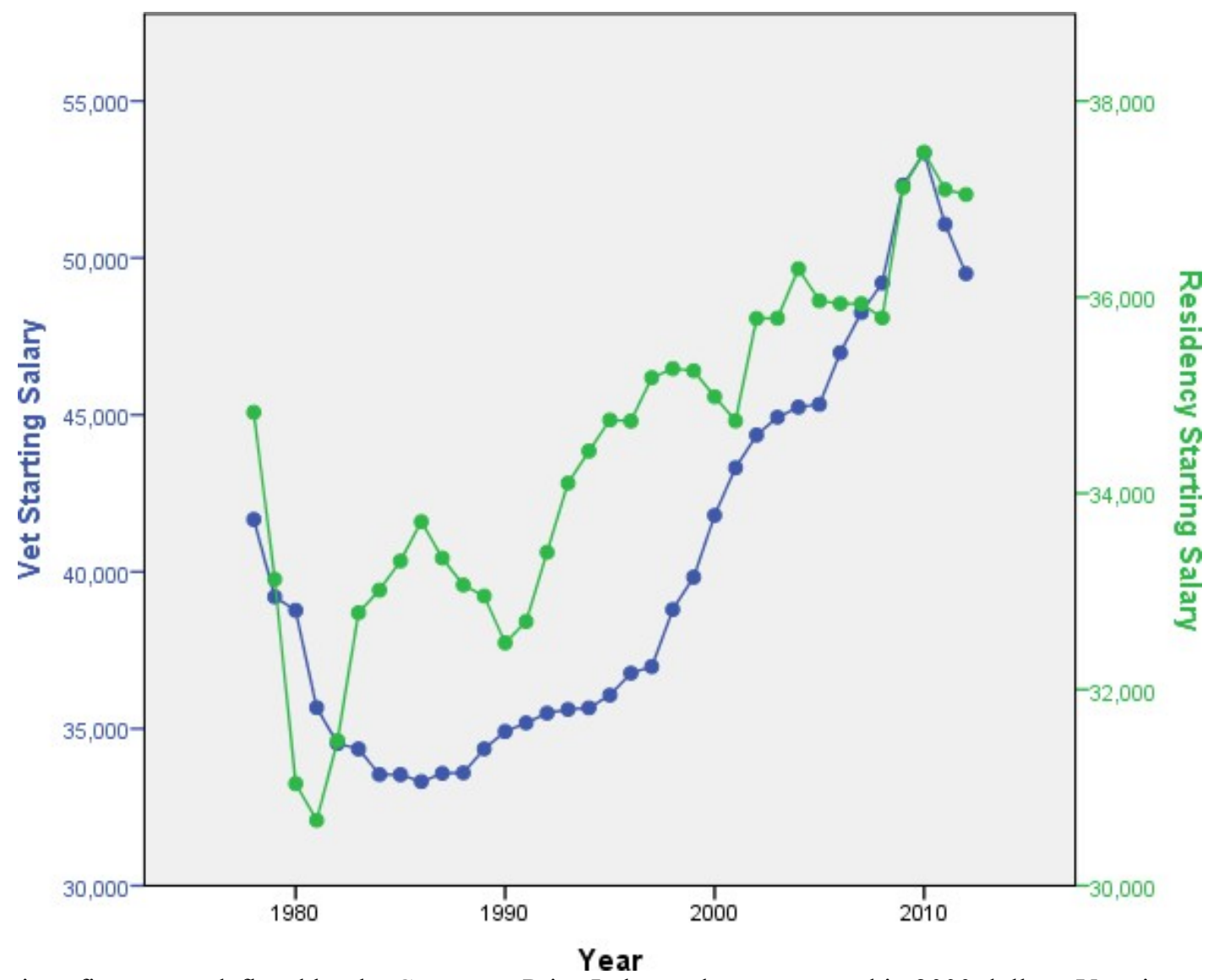

All earnings figures are deflated by the Consumer Price Index and are expressed in 2000 dollars. Veterinary starting salaries are reported as means for 1978-2001, and medians for 2002-2012.

Sources:

- American Veterinary Medical Association. Starting Salaries for Veterinary College Graduates. Journal of the American Veterinary Medical Association. Schaumburg, IL.

- American Association of Medical Colleges. Survey of Resident/Fellow Stipends and Benefits Report, 201314. Washington DC.

Overall, variation in the veterinarian starting salary data presented in Figure 2 could be driven by fluctuating employment in the veterinary labor market. Falling real earnings from 1978 to 1986 could result from an "oversupply" of veterinary graduates due to relatively large first-year enrollments from 1974 to 1982 (see Figure 1). Increasing real earnings since 1986 could result from an "undersupply" of veterinary graduates due to a relative decline in first-year enrollments since $1982 .^{3}$

Alternatively, these fluctuations in earnings could result from changes in demand, not in supply. In a quantitative examination of a particular labor market, the analysis must include a convincing measure of labor demand. For lawyers, engineers, and physicists, Freeman (1976) utilized various government data on national output, consumer spending, and government budget outlays. This task presents a challenge for veterinarians, as the government keeps few statistics relevant to the veterinary profession. Although the U.S. Department of Agriculture conducts annual surveys on the livestock population, the AVMA estimates that only $11 \%$ of veterinarians directly care for the livestock population. Since most veterinarians care for small animals, a more direct measure of demand for veterinary services would be based on the size of the pet population. 
Serving as a proxy for the size of the pet population in our analysis is the total value of shipments for the dog and cat food industry, as reported in the U.S. Department of Commerce's Annual Survey of Manufactures, for the years 1972 to 2011. Fig. 3 reports this measure of demand over time. The measure of pet food shipments exhibits some cyclical variation but trends upward over the period of consideration. When comparing Figs. 2 and 3, it is unclear whether the variation in demand is correlated with changes in earnings. An econometric analysis of the veterinarian labor market is necessary to separate supply and demand effects on earnings.

\section{FIGURE 3 \\ VETERINARY DEMAND, 1972-2011}

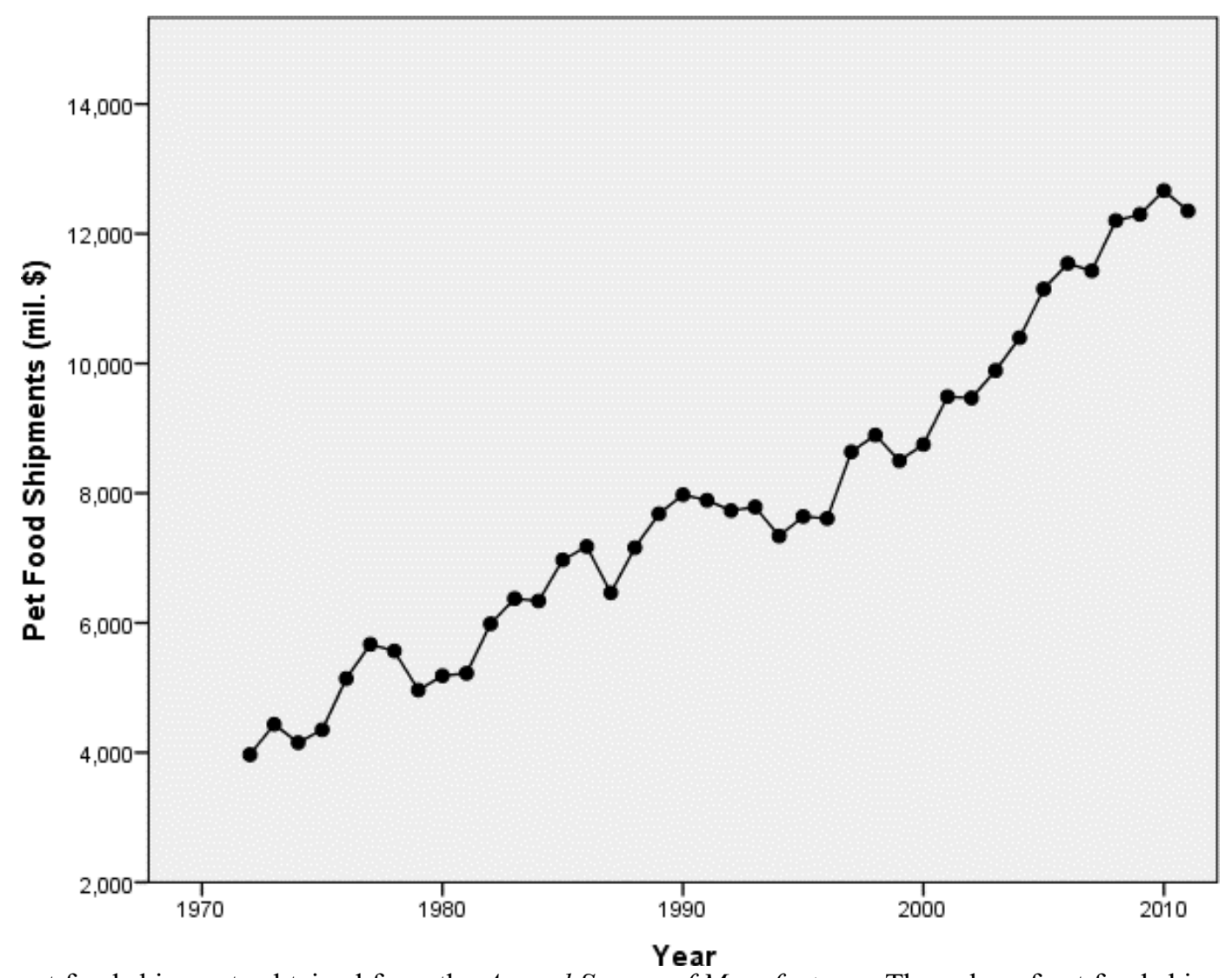

Data on pet food shipments obtained from the Annual Survey of Manufactures. The value of pet food shipments has been deflated by the corresponding producer price index and is expressed in 2000 dollars.

Sources:

- U.S. Department of Commerce, Bureau of the Census. Annual Survey of Manufactures. Washington DC.

\section{EMPIRICAL MODEL}

Undergraduates with an interest in Veterinary Medicine will likely have many career options available to them. From prior economic studies, a primary influence on occupational choice is lifetime earnings potential. Early in their undergraduate programs, individuals focus on occupations with the best prospects for future success as they make critical curricular choices (i.e., pre-med, pre-engineering, etc.). We use a progressive approach to model-building that permits estimation of essential features affecting the choice of academic major during the undergraduate years and current and predictable conditions in the desired labor market. We also assume that individual decisions are based on opinions about desirable labor markets, which can be identified by a comparative analysis of earnings in those markets. 
Our study partitions determinants of the market for veterinary school entrants into three components: supply of new veterinarians, supply of bachelor degree graduates, and all other pertinent, causal factors presumably affecting salary for the veterinary profession. Factors hypothesized as being relevant to the veterinary labor market are listed in Table 3. Please note that all variables used in the model are logtransformations so that elasticities may be easily estimated using our final models.

TABLE 3

ECONOMIC MODEL VARIABLE LIST

\begin{tabular}{|c|c|c|}
\hline Variable & Explanation & Source \\
\hline BachTot and & Total bachelor degree recipients. & The U.S. Department of Education \\
\hline DVMGrads t-3 & $\begin{array}{l}\text { Total Doctor of Veterinary Medicine } \\
\text { (DVM) graduates lagged three years. }\end{array}$ & $\begin{array}{l}\text { reports bachelor and DVM degrees } \\
\text { granted each year. Two publications, } \\
\text { Earned Degrees Conferred and the } \\
\text { Digest of Education Statistics, were } \\
\text { used over the period over consideration. }\end{array}$ \\
\hline BSChem & $\begin{array}{l}\text { BS in Chemistry starting salary } \\
\text { adjusted for inflation as measured by } \\
\text { the CPI to the year } 2000 \text { dollars. }\end{array}$ & $\begin{array}{l}\text { National Association of Colleges and } \\
\text { Employers in a quarterly publication } \\
\text { titled the CPC Salary Survey. The } \\
\text { publication title has changed to the } \\
\text { National Association of Colleges and } \\
\text { Employers Salary Survey for the most } \\
\text { recent years. }\end{array}$ \\
\hline PetFood t-3 & $\begin{array}{l}\text { Total industry value of pet food } \\
\text { shipments adjusted for inflation as } \\
\text { measured by PPI for the year } 2000 \\
\text { dollars lagged three years. }\end{array}$ & $\begin{array}{l}\text { U.S. Department Commerce's Annual } \\
\text { Survey of Manufactures. }\end{array}$ \\
\hline $\begin{array}{l}\text { Fresh } t \text { and } \\
\text { StartVSal } t-3\end{array}$ & $\begin{array}{l}\text { Enrolled first-year DVM students in } \\
\text { time t, and starting salary of } \\
\text { Veterinary Medicine (DVM) } \\
\text { graduates lagged three years. }\end{array}$ & $\begin{array}{l}\text { Surveyed by the Association of } \\
\text { American Veterinary Medical Colleges } \\
\text { and reported annually in the Journal of } \\
\text { the American Veterinary Medical } \\
\text { Association }\end{array}$ \\
\hline
\end{tabular}

Cobweb theory suggests that many students will choose to enter veterinary school when salaries are high for those in the profession. Since veterinary school applicants must complete at least two years of preveterinary training in the sciences, we assume that key indicators of salary and demand would be observed during the sophomore year (i.e., three years before graduation). This assumption is consistent with the findings of Betts (1996), Dominitz \& Manski (1996), Diebolt et al. (2003, 2004), Billiot et al. (2004), Ryoo (2004), Lee (2010), all of whom found that students acquire information about earnings early on in their college careers. Feldman \& Scheffler (1978) have also demonstrated a 3-year lag between application decision and entry for medical students in a study of the physician labor market. The following supply equation may now summarize our hypothesized, operational view of the veterinary labor market:

$$
\begin{aligned}
\text { Fresh }_{t} & =a_{1} \text { PetFood }_{t-3}+a_{2} \text { BSChem }_{t}+a_{3} \text { DVMGrads }_{t-3} \\
& +a_{4} \text { BachTot }_{t}+a_{5} \text { StartVSal }_{t-3}+e
\end{aligned}
$$

Demand-side variables included in our model are: an exogenous demand-shift variable - the value of pet food shipments, lagged three time periods; and a measure of opportunity wage. We have included this estimate of opportunity wage, believing that when alternative (and possibly more compelling) occupations exist after undergraduate training, it is possible that some students will decide to pursue those careers instead and will not apply to veterinary school. As such, we include the starting salaries for Bachelor of 
Science in chemistry recipients at time t. The key supply-side variable is veterinary school graduates at time $\mathrm{t}-3$, a principal cause of cyclical fluctuations in the market for veterinarians. To control for demographic changes in college graduates, we include the number of bachelor degree recipients at time t. Finally, we include a measure of starting salary at time $\mathrm{t}-3$ for new veterinarians.

\section{RESULTS}

We note that the Durbin-Watson test for independence of error terms was rejected in our preliminary estimations, making it necessary to apply the Cochrane-Orcutt correction (see Greene, 2017). Parameter estimates from our hypothesized model are reported in Table 4.

TABLE 4

\section{COBWEB MODEL}

\begin{tabular}{lrrr}
\hline Variable & Coefficient & Std Error & \multicolumn{2}{c}{ P-Value } \\
\hline Intercept & 6.421 & 1.658 & .001 \\
PetFood t-3 & .197 & .071 & .010 \\
BSChem & -.208 & .091 & .031 \\
DVMGrads t-3 & -.137 & .080 & .098 \\
BachTot & -.208 & .166 & .222 \\
StartVSal t-3 & .542 & .155 & .002 \\
N=28 & & & \\
R-squared & 0.886 & Durbin-Watson statistic (original) & .817 \\
Adj. R-squared & 0.860 & Durbin-Watson statistic (transformed) & 1.841 \\
\hline
\end{tabular}

Notes: All variables are in log form. All salary figures are deflated by the Consumer Price Index. The estimation technique is Cochrane-Orcutt.

A key coefficient is that for graduates at $\mathrm{t}-3$, a measure of supply, which according to cobweb theory should be negative. A large graduating class in year $\mathrm{t}-3$ will negatively impact starting salaries, inducing a smaller supply of first-year students in year $t$ (and a smaller graduating class in $t+4$, seven years after the enrollment decision). The coefficient is negative and statistically significant $(\mathrm{p}<.10)$, suggesting that a $10 \%$ increase in graduates in year $\mathrm{t}-3$ reduces first-year enrollments in year $\mathrm{t}$ by approximately $1.4 \%$. As expected, the coefficient for veterinary starting salaries is positive and highly significant $(p<.01)$, indicating a direct effect of salary on first-year enrollment. The estimated coefficient suggests that a $10 \%$ increase in veterinarian starting salaries leads to an approximate 5.4\% increase in first-year enrollments three years later. The coefficient for the exogenous demand-shift variable is also positive, as expected, and highly significant $(\mathrm{p}<.01)$. The estimated coefficient suggests that a $10 \%$ increase in pet food shipments leads to an approximate $2 \%$ increase in first-year veterinary school enrollments three years later. Concerning the possible effects of alternative professional opportunities, we note that the coefficient on starting salaries for Bachelor of Science Chemistry recipients is negative and statistically significant $(\mathrm{p}<.05)$. The estimated coefficient suggests that a $10 \%$ increase in starting salaries for B.S. recipients will result in an approximate $2.1 \%$ decline in veterinary school enrollments. The coefficient on our control variable - bachelor degree graduates - is negative in this sample but statistically insignificant. A post-estimation collinearity test suggested a relatively high level of collinearity between bachelor's degree recipients $(t)$ and the pet food shipments (t-3). This may explain why the coefficient on degree recipients is statistically insignificant and also contributes to the relatively high adjusted R-squared of .86.

\section{DISCUSSION}

When discussing forward-looking expectations, as Siow (1984) notes, it is essential to distinguish between rational expectations, in the sense of Muth (1961), and perfect foresight. With rational 
expectations, an agent forecasts future market conditions based on current and past information. Wolter (2000), in his study of the occupational choices of Swiss students, concludes that we should expect human capital investors to use current information on labor markets to estimate future earnings. In this sense, using current wage information to predict future earnings is entirely "rational." Human capital investors may be making sophisticated forecasts of life-cycle earnings for alternative professions, but due to discounting, these life-cycle earnings patterns are highly correlated with current earnings data, as Flyer (1997) discovered. Thus, cobweb models tend to describe labor market data reasonably well, particularly in occupations closely linked with professional training.

Finding data that fit the cobweb model well does not, in and of itself, negate the possibility of forwardlooking expectations models. Forward-looking models can also generate cyclical fluctuations due to occupational immobility in professional labor markets. Unanticipated shocks in demand can lead to fluctuations in employment and earnings due to the time lag between occupational choice and entry. ${ }^{4}$ Thus, the same data may fit both models well, as Zarkin (1985) found in his study of public school teachers. This result makes it difficult to advocate one model over another.

In the works noted earlier, few authors, with Borghans, de Grip, and Heijke (1996) a notable exception, explicitly test the fit of both cobweb and rational expectations models. Our model tests the notion that agents respond to demand conditions independent of starting salary information. Myopic expectations models assume that agents respond only to current information on starting and alternative salaries. If agents' occupational choices are independently affected by demand conditions, there is some evidence that agents make forecasts of future market conditions based on current information sets. Such forecasting would be consistent with Muth's rational expectations theory. Our results are favorable to this hypothesis. The coefficient on the demand variable is statistically significant, and this model exhibits greater explanatory power than when the demand variable is excluded. Our model suggests that pre-veterinary students use more information than starting salary alone when making decisions about a graduate major. Such behavior is consistent with the rational expectations model.

To further explore students' ability to act rationally, we posit whether students may be cognizant of possible interactive effects among economic variables, particularly the interaction between starting salary and demand. We include variables that were estimated as statistically significant in our prior specification, in addition to a new interaction term. The estimated equation is:

Fresh $_{t}=a_{1}$ PetFood $_{t-3}+a_{2}$ BSChem $_{t}+a_{3}$ DVMGrads $_{t-3}+a_{4}$ StartVSal $_{t-3}$ $+a_{5}$ StartVSal $_{t-3} *$ PetFood $_{t-3}+e$

Results from this analysis are summarized in Table 5. Notably, the interaction term (salary*demand in $\mathrm{t}-3)$ is positive and significant $(\mathrm{p}<.05)$, indicating that the effect of salary on veterinary school enrollment may depend upon the level of demand and vice versa. This result suggests that human capital investors may be reasonably savvy about occupational choices. They make an effort to predict salary performance but recognize that a secondary factor, namely demand, can influence the effect of salary on occupational choice. Thus, if demand and veterinary graduate salaries are both high, human capital investors predict that the overall impact on their wages will be even higher salaries and decide to invest in veterinary training. This would also hold in a scenario where demand and starting salaries were low - in this case, human capital investors would be less likely to enroll in veterinary school. This phenomenon represents a level of "rational choice" at a greater level than revealed by our original model. The adjusted R-squared of .939 suggests a very good fit, though potential collinearity impacts are greater with the addition of an interaction term in the regression, confirmed with a post-estimation collinearity test. 
TABLE 5

COBWEB MODEL WITH INTERACTION

\begin{tabular}{lrrr}
\hline Variable & Coefficient & Std Error & P-Value \\
\hline Intercept & 53.856 & 18.067 & .006 \\
PetFood t-3 & -5.231 & 1.969 & .013 \\
BSChem & -.122 & .080 & .139 \\
DVMGrads t-3 & -.146 & .074 & .059 \\
StartVSal t-3 & -.426 & 1.725 & .020 \\
StartVSal t-3* & .509 & .187 & .006 \\
PetFood t-3 & & & \\
N=30 & & & \\
R-squared & 0.950 & Durbin-Watson statistic (original) & 1.332 \\
Adj. R-squared & 0.939 & Durbin-Watson statistic (transformed) & 1.929 \\
\hline
\end{tabular}

Notes: All variables are in log form. All salary figures are deflated by the Consumer Price Index. The estimation technique is Cochrane-Orcutt.

Prior work has shown the importance of wages in decisions related to schooling and occupational choice (e.g., Ashworth et al. 2020). Studies at the individual level can provide significant insight into school and occupational choice, particularly when considering potential wide variation in the cost and quality of schooling. However, veterinary training programs have some unique characteristics that may lend themselves to a macro perspective. Due to accreditation, the curriculum at the 28 accredited veterinarian programs is relatively standardized, which leads to somewhat similar costs and similar career opportunities. Lloyd (2013) details the increasing debt burdens that veterinary students have to bear with reducing state government support. According to the AVMA (2016), nearly 90 percent of students graduate with debt, and the average debt exceeds $\$ 140,000$, more than twice the average starting salary for a veterinarian.

White et al. (2020) have conducted a comprehensive analysis of individual veterinary school costs and career outcomes for veterinary school graduates over a 25 -year career. They use this data to estimate an NPV among veterinary school choices. There is variation across schools, the range is from $\$ 1,175,155$ at the University of Pennsylvania to $\$ 1,740,257$ at Purdue University for resident students, but most schools cluster around \$1.4-1.5 million in NPV. Though a macro perspective does not model the specific decisions of human capital investors, we contend that it can still provide insight into labor market dynamics, particularly when examining professions with training programs that are relatively homogenous in cost and quality.

\section{SUMMARY AND CONCLUSIONS}

Outcomes of our study may be summarized as follows: First, salaries (new veterinarians and B.S. in chemistry recipients) have a significant effect on veterinary school enrollments; veterinary starting salaries have a positive effect and salaries for new positions in chemistry have a negative impact. Second, there is a strong correlation between veterinary graduates (lagged three time periods) and veterinary school enrollments. Third, our model suggests that the exogenous demand variable - pet food shipments positively and significantly affects veterinary school enrollments. In addition, there is an interaction effect (multiplicative) on veterinary school enrollments associated with the salary and demand variables.

In conclusion, we find that the labor market for veterinarians appears to be characterized by the cyclical fluctuations found in other professional labor markets. A cobweb model fits the data well, and our results are fairly consistent with the findings of previous researchers who have studied engineers, lawyers, teachers, and physicists. A significant finding is that the veterinary labor market appears to be characterized by a seven-year lag between occupational choice and graduation. However, the cobweb model does not tell the whole story. Our investigation of the forward-looking expectations models offers evidence for the rational expectations model in the sense of Muth, as investors appear to respond to other variables beyond starting 
salaries in making enrollment decisions. This finding could mean that human capital investors are making forecasts based on currently available information sets. These forecasts are made with error, of course, demonstrated by the cyclical nature of employment and earnings data, and thus there continues to be a need for the professional forecaster. However, our results support the notion that human capital investors forecast future market conditions as best they are able from the current information sets.

The time series used to generate our econometric model is relatively short (28-30 years), and the estimates are sensitive to various specifications. Thus, inferences from such estimates need to be made with caution. With these caveats in mind, when juxtaposing the myopic and rational expectations models as two different versions of reality, perhaps the truth of how human capital investors form earnings expectations lies somewhere in between. Results presented here support this notion, as aspects of both myopic and rational expectations models appear to hold for human capital investors in the labor market for veterinarians. These findings have implications for other labor markets in which significant human capital investments are made.

\section{ENDNOTES}

1. There are 28 colleges of veterinary medicine accredited by the American Veterinary Medical Association: Auburn, California-Davis, Colorado State, Cornell, Florida, Georgia, Illinois, Iowa State, Kansas State, Louisiana State, Michigan State, Minnesota, Mississippi State, Missouri, North Carolina State, Ohio State, Oklahoma State, Oregon State, Pennsylvania, Purdue, Tennessee, Texas A \& M, Tufts, Tuskegee, VirginiaMaryland, Washington State, Western University-California, and Wisconsin.

2. Deflated by the Consumer Price Index, real earnings for veterinarians were greater in 1970 than in 2000 . However, given evidence that the CPI overstates the rate of inflation, changes in relative earnings should receive greater consideration.

3. In a study of 193 occupations from 1989-93, utilizing a variety of employment indicators, Cohen (1995) ranks veterinarians as the second-highest occupation demonstrating a shortage of labor.

4. Felderer and Drost (2000) provide a model which demonstrates that employment fluctuations can be generated even without the assumption of occupational immobility.

\section{REFERENCES}

Altonji, J.G., Blom, E., \& Meghir, C. (2012). Heterogeneity in human capital investments: High school curriculum, college major, and careers. Annual Review of Economics, 4(1), 185-223.

Ashworth, J., Hotz, V.J., Maurel, A., \& Ransom, T. (2021). Changes across cohorts in wage returns to schooling and early work experiences. Journal of Labor Economics, 39(4), 931-964.

Bain, B., \& Dick, M. (2016). Are veterinary students accumulating unreasonable amounts of debt? Journal of the American Veterinary Medical Association, 249(3), 285-288.

Berger, M.C. (1988). Predicted future earnings and choice of college major. ILR Review, 41(3), 418-429.

Betts, J.R. (1996). What do students know about wages? Evidence from a survey of undergraduates. Journal of Human Resources, 31(1), 27-56.

Billiot, M.J., Glandon, S., \& McFerrin, R. (2004). Factors affecting the supply of accounting graduates. Issues in Accounting Education, 19(4), 443-467.

Borghans, L., de Grip, A., \& Heijke, H. (1996). Labor market information and the choice of vocational specialization. Economics of Education Review, 15(1), 59-74.

Clark, B. (2016). Essays in the economics of education (Ph.D.). Available from EBSCOhost; ecn. (1606918).

Cohen, M.S. (1995). Labor shortages as America approaches the twenty-first century. Ann Arbor: University of Michigan Press.

Connelly, R. (1989). Occupational choice under uncertainty when experience is a determinant of earnings. Econometrica, 57(5), 1215-1219.

Diebolt, C., \& El Murr, B. (2003). A model of glutting: Human capital and labour markets in the longrun. Applied Economics Letters, 10(9), 557-560. 
Diebolt, C., \& Murr, B.E. (2004). Educational development and labour markets. Quality \& Quantity: International Journal of Methodology, 38(2), 127-145.

Dominitz, J., \& Manski, C.F. (1996). Eliciting student expectations of the returns to schooling. Journal of Human Resources, 31(1), 1-26.

Ezekiel, M. (1938). The cobweb theorem. Quarterly Journal of Economics, 52, 225-280.

Felderer, B., \& Drost, A. (2000). Cyclical occupational choice in a model with rational wage expectations and perfect occupational mobility. Unpublished manuscript.

Feldman, R., \& Scheffler, R.M. (1978). The supply of medical school applicants and the rate of return to training. Quarterly Review of Economics and Business, 18(1), 91-98.

Flyer, F.A. (1997). The influence of higher moments of earnings distributions on career decisions. Journal of Labor Economics, 15(4), 689-713.

Freeman, R.B. (1975). Legal 'cobwebs': A recursive model of the market for new lawyers. Review of Economics and Statistics, 57(2), 171-179.

Freeman, R.B. (1975). Supply and salary adjustments to the changing science manpower market: Physics, 1948-1973. American Economic Review, 65(1), 27-39.

Freeman, R.B. (1976). A cobweb model of the supply and starting salary of new engineers. Industrial and Labor Relations Review, 29(2), 236-248.

Freeman, R.B. (1976). The overeducated American. New York: Academic Press.

Freeman, R.B. (1989). Labor markets in action: Essays in empirical economics. Cambridge and London: Harvard University Press.

Greene, W.H. (2017). Econometric analysis (8th ed.). New York, NY: Pearson.

Haas, J. (2005). The situation in industry and the loss of interest in science education. European Journal of Education, 40(4), 405-416.

Hoffman, D.L., \& Low, S.A. (1983). Rationality and the decision to invest in economics. Journal of Human Resources, 18(4), 480-496.

Lee, U. (2010). The impact of labor market conditions on choice of college major. UMI Dissertation Publishing, ProQuest LLC.

Leffler, K.B., \& Lindsay, C.M. (1979). How do human capital investors form earnings expectations? Southern Economic Journal, 46(2), 591-602.

Lloyd, J.W. (2013). Financial dimensions of veterinary medical education: An economist's perspective. Journal of Veterinary Medical Education, 402(2), 85-93.

Long, M.C., Goldhaber, D., \& Huntington-Klein, N. (2015). Do completed college majors respond to changes in wages? Economics of Education Review, 49, 1-14.

Muth, J.F. (1961). Rational expectations and the theory of price movements. Econometrica, 29, 315-335.

Ryoo, J., \& Rosen, S. (2004). The engineering labor market. Journal of Political Economy, 112(1), S110 40.

Siow, A. (1984). Occupational choice under uncertainty. Econometrica, 52(3), 631-645.

United States, Bureau of Labor Statistics. (2014). 2014-2015 Occupational Outlook Handbook.

Weinstein, R. (2017). Local labor markets and human capital investments. Institute for the Study of Labor (IZA). Retrieved from https://EconPapers.repec.org/RePEc:iza:izadps:dp10598

White, A., Neill, C., \& Holcomb, R. (2020). Does it pay to go to school: The returns above veterinary school expenses. Unpublished manuscript.

Wolter, S.C. (2000). Wage expectations: A comparison of Swiss and US students. Kyklos, 53(1), 51-69.

Zarkin, G.A. (1985). Occupational choice: An application to the market for public school teachers. Quarterly Journal of Economics, 100(2), 409-446. 